\title{
The Path to 9/11 vs. Stuff Happens: Media and Political Efficacy in the War on Terror
}

\author{
Jay M. Gipson-King
}

On September 10 and 11, 2006, the ABC television network aired a two part miniseries entitled The Path to 9/11, which dramatized the build up from the 1993 bombing of the World Trade Center to the September 11 terrorist attacks. Initial advertisements claimed the miniseries was "based on the 9/11 Commission Report," and both the director and the screenwriter bragged of the film's accuracy. ${ }^{1}$ Nine days before the miniseries aired, members of the Clinton administration caused a small controversy when they wrote a letter to $\mathrm{ABC}$ claiming that "the content of this drama is factually and incontrovertibly inaccurate," and that, "while ABC is promoting 'The Path to $9 / 11$ ' as a dramatization of historical fact, in truth it is a fictitious rewriting of history that will be misinterpreted by millions of Americans." Former Secretary of State Madeline Albright and former National Security Advisor Sandy Berger accused the film of slander, and average citizens wrote letters of protest by the thousands. ${ }^{3}$

Exactly two years earlier on September 10, 2004, a new play premiered at the National Theatre in London: David Hare's Stuff Happens. The play depicts the George W. Bush administration's push toward the invasion of Iraq, covering the period from 2001 to early 2004. It advanced what was at the time a disputed proposition, that the invasion was a premeditated affair based on fabricated evidence. The play's opening was heralded as the return of political theatre to the London stage. ${ }^{4}$ Although there were some dissenters, it was by and large praised for its ideological balance, and even Hans Blix, the United Nations Weapons Inspector, commended its credibility. ${ }^{5}$ One Member of Parliament called it "crude propaganda," but the worst rebuke it received was a quintessentially True Brit remark from Tony Blair to the play's director at a cocktail party: "Well, you're giving us a hard time, aren't you?" Stuff Happens has henceforth become part of the canon of contemporary British theatre.

These two historical narratives address the "war on terror" from a sweeping, top-down point of view, each taking the September 11 attacks as either the beginning or end of the dramatic conflict. Both depict high ranking government officials as their central characters - many of whom were still in office when the pieces

Jay M. Gipson-King is an instructor of theatre at Chemeketa Community College in Salem, Oregon and a Ph.D. candidate at Florida State University. He has previously published on the use of time and history in the work of Timberlake Wertenbaker, and has presented on contemporary British theatre at numerous conferences, including the 2009 international Howard Barker conference in Aberystwyth, Wales. 
premiered. Both possessed the potential for political controversy, as each made an implicit case either for or against the continuation of the U.S.-led occupation of Iraq, which was in the full throes of its anti-insurgency campaign during this time period. However, despite the similarities in content, these two pieces provoked polar opposite reactions in their respective countries, which gives rise to a series of critical paradoxes. For example, while the creators of both pieces vociferously asserted their accuracy, ${ }^{7}$ pundits lauded the play for its fairness and condemned the television program as egregiously biased. Hare's reputation as a notorious leftist made the praise of political even-handedness for Stuff Happens even more surprising. At the same time, both narratives explicitly claimed not to be documentaries, a position that not only contradicts their insistence upon accuracy, but begs the question: if the television program had been judged by the rules of a theatrical history play, would it still have provoked such a violent reaction from members of the Clinton administration? Lastly, Stuff Happens was an epic play (both in scope and style), written by a world renowned playwright, performed on the stage of England's National Theatre, and yet it barely caught the attention of Britain's political leaders. The Path to 9/11, on the other hand, was a "made-for-TV-movie" - a genre that evokes images of "based-on-a-true-story" melodramatic adventures rather than political agitation - and yet it brought down the wrath of some of the highest ranking statesmen in the country. These opposite reactions invert the position that most theatre scholars and artists like to hold, that while television drama may be widely popular, live performance remains culturally important.

What this comparison boils down to is a matter of political efficacy: Is the ability of theatre to impact the political landscape — even as a gadfly —insignificant compared to television? The subtleties of political influence are difficult to measure, barring a controlled survey of audience opinion. However, performance has the ability to challenge core beliefs, and when a play or teleplay scores a hit on such beliefs, it creates an immediate, observable result: it generates an inordinate amount of anger. Under this definition of political efficacy, the television program wins decisively. In terms of sheer numbers, the miniseries' two-night viewership of twelve million eclipses the number of people who have seen Stuff Happens in six years. However, despite the scope of The Path to 9/11, Stuff Happens has shown an impressive longevity as it continues to be revived across the Anglophone world. In the long term, the play may have much greater influence in shaping future perceptions of the war on terror. This paper, then, will explore the different aspects of media, credibility, and historiography between the two works: Why did one create a political uproar and the other not? Why was one piece perceived as historically truthful, and the other not? I will examine the conditions of emergence of each piece in turn before exploring how the increasing political effectiveness of Stuff Happens matches - and could eventually overcome - the sudden impact of The Path to $9 / 11$. 


\section{Stuff Happens: A Credible Fiction}

Stuff Happens premiered on the Olivier stage of the National Theatre in London under the direction of Nicholas Hytner, the National's artistic director. It opened eighteen months after U.S. and British forces invaded Iraq on March 19, 2003. In March 2004, President Bush joked about finding weapons of mass destruction at the White House correspondents' dinner. In April, the first of the Abu Ghraib photographs were revealed, and coalition forces failed to wrest Fallujah from the control of insurgents despite a huge cost in lives on both sides. In September, U.S. casualties had just topped 1,000, while the British death toll stood at 60 . On the Iraqi side, over 18,400 civilians had been killed. ${ }^{8}$ Against this backdrop, Hare presented his version of the path to war in theatrical form. As Hare put it, "if you want to know what happened with Blair, and Bush, and Powell and company, and you want to get it all in one evening, you have to go to the play." Stuff Happens employs twenty-two actors depicting forty-nine characters, but the story focuses on the most powerful members of the Bush and Blair administrations: Bush, Blair, Vice President Dick Cheney, Secretary of Defense Donald Rumsfeld, and National Security Advisor Condaleeza Rice. Secretary of State Colin Powell becomes the tragic protagonist of the piece, as he is the only member of the Bush cabinet to oppose the war, and yet, he, too, capitulates in the end. The plot begins with a meeting of Bush's National Security Council in early 2001, in which Iraq's capacity to produce weapons of mass destruction was under discussion. The play then moves quickly through September 11 and the invasion of Afghanistan to Bush's warning against the "axis of evil" and his escalating accusations against Iraq. Act two depicts the nuanced negotiations between the U.S., the U.K., and the United Nations as the U.S. pursues a resolution for war. The action ends as Bush and Blair abandon those negotiations and launch the invasion, and the play closes with a speech from an Iraqi exile lamenting the "crucifixion" of his country: "If you don't [take charge] yourself, this is what you get."

David Hare has long held a reputation as an outspoken leftist, starting in his early days working with Howard Brenton in the agitprop troupe Portable Theatre and continuing through his "National Theatre Trilogy" in the early 1990s, which critiqued the British institutions of church, law, and parliament. ${ }^{11}$ Nor were his feelings about the Iraq war in any way neutral; he had published two scathing editorials in The Guardian in 2003, accusing Bush of manufacturing the war and lambasting Blair for capitulating to him. ${ }^{12}$ Hare's public stance against the war led more than one reviewer to go into Stuff Happens expecting “a thinking-man's Fahrenheit 9/11."13 However, that is not at all what they saw. Of the thirty-five critics who reviewed the original production, over two-thirds considered the play balanced, accurate, and convincing. In addition to the endorsement from Hans Blix, who confirmed some of the play's behind-the-scenes details, the play received 
praise from Robin Cook, former leader of the House of Commons who resigned in protest over the war; Lt. Colonel Tim Collins, who led a British battle group during the invasion; and Scott Ritter, the chief United Nations Weapons Inspector in Iraq until 1998. London newspaper critics noted Hare's "exhaustive research" and "amazing scholarship." 14 John Nathan of the Jewish Chronicle insisted that "Hare does not distort the facts in order to make a point-rather he sticks to them," while even the conservative Charles Spencer of the Daily Telegraph called the play "admirably fair and even-handed. Its message is clear, and I think increasingly irrefutable. .. . I believe him."15

So what gave Stuff Happens its aura of authenticity in contrast to its author's partisan reputation? The difference stems in part from the play's method of keeping one foot in the realm of fiction and the other in the realm of documentary theatre, as Hare explains in a note included in the program and the published script:

Stuff Happens is a history play, which happens to center on very recent history. The events within it have been authenticated from multiple sources, both private and public. What happened happened. Nothing in the narrative is knowingly untrue. Scenes of direct address quote people verbatim. When the doors close on the world's leaders and on their entourages, then I have used my imagination. This is surely a play, not a documentary, and driven, I hope, by its themes as much as by its characters and story. ${ }^{16}$

Hare makes a curious assertion here, claiming the rights of both fiction and nonfiction. The play in fact operates at three levels of reality: approximately one quarter of the play is composed of direct quotes from the public record. These were easily distinguished in the original performance, as all such speeches were delivered directly to the audience and were framed by a narrative introduction presenting the speaker and the context, such as a press conference, interview, or other public forum. The second level of reality I call "informed speculation" and encompasses the scenes that take place behind closed doors. Hare claims to have spoken with sources from both the White House and Downing Street, although he has kept them strictly anonymous. His speculations do correspond with accounts from some of the key players, such as Central Intelligence Agency Director George Tenet and British Foreign Secretary Jack Straw, whose memoirs were published after the play premiered. ${ }^{17}$ Contemporary British theatre scholar Donna Soto-Morettini further observes that "the events that Hare portrays . . closely follow Washington Post journalist Bob Woodward's account in Plan of Attack," published just a few months prior to the play's opening. ${ }^{18}$ The proliferation of substantiating documentation increased the credibility of scenes that take place ostensibly in private. The third level of reality is that of pure imagination, scenes in which no one knows what 
happened except the people who were there. For example, in 2002, the real-life Bush and Blair took a six hour walk in Crawford, Texas, during which no one-neither spouses nor aides - went with them. In recreating this scene, Hare was forced to extrapolate from the two leaders' speeches made immediately before and after the encounter, as well as their later actions. Hare's dramatization therefore becomes an act of invention-which is not to say that it is necessarily untrue; the facts are simply unknown to everyone except Bush and Blair.

Over the course of the play, the various layers of fact and fiction blend into each other, with documented parts lending credence to imaginative parts. Theatre scholar Stephen Bottoms, in his article on recent docudramas, claims that Hare "actively muddies the waters of the 'real' by using the same narrator-based subtitling strategy to introduce characters in the made-up scenes as he does in the avowedly verbatim sequences, " suggesting that the play assumes an authority it does not really have. ${ }^{19}$ Christopher Rawson, reviewer of a Pittsburgh production, reported that "the play certainly feels like a documentary, so audiences are often surprised to hear that so much of it is invented." Hare himself has gone back and forth on the accuracy issue, at times admitting that the play is "three-fourths fiction," 20 and insisting at others that "I didn't embroider. I imagined. . . . I've speculated about it, but my speculations are very well-sourced, from multiple sources." ${ }^{21}$ Despite the apparent contradiction in his statements I do not think Hare is being disingenuous here. The first claim reflects the impulse of the artist, who wants to take credit for the creative aspects of the play, and the second reflects the pride of the researcher, who wants his findings taken seriously. ${ }^{22}$

In performance, the combination of authenticated sources and dramatic imagination seems to have increased the perceived credibility of the play. After all, the charge of inaccuracy cannot be leveled at a play that claims to be fiction, while Hare's insistence on the use of reliable sources gives even the imaginative scenes a weight of authority. As New York Times critic Ben Brantley wrote, "this greater openness about his dramatic methods has the paradoxical effect of making me trust more the undocumented moments in Stuff Happens. ${ }^{~} 23$ In any case, as Hare is fond of pointing out, no official sources have ever stepped forward to challenge the play, not even the revelation that in November 2001 British special forces were within striking distance of Osama bin Laden but were ordered to pull back by the U.S. military. ${ }^{24}$ Many of Hare's other speculations have been validated over time, particularly the main thrust of the play, that the invasion was premeditated and the evidence fabricated. Hare notes that "the claims the play makes were controversial at the time. . . It has now become standard history." 25

Furthermore, Hare's partisan reputation actually worked in his favor to increase the overall perception of the play as fair and balanced, so much so that Kate Bassett remarked in The Independent on Sunday, "in the early scenes you 
start wondering if Hare, the famous Hampstead left-winger, has decided it's time for a swing to the right." ${ }^{26}$ Hare accomplished this remarkable shift in perception through two main methods. First, he includes several "viewpoints"-monologues that take place outside the narrative of the play-some of which include the pro-war argument. The first such viewpoint comes from an "angry journalist" who accuses the Western nations of hypocrisy for liberating a people and then complaining of the manner in which it was done. If a European dictator had committed the same crimes as Saddam Hussein, he suggests, no one would argue against his forceful removal. ${ }^{27}$ As critic Toby Young of The Spectator observed, "to see a character in a play directly challenge the point of view that must be shared by at least 75 per cent of the audience-and to do so with such eloquence-is quite something., ${ }^{28}$ Secondly, Hare gives real teeth to Bush and his cabinet members. The greatest surprise to both British and American audiences is that Bush himself comes across not as a bumpkin but as the shrewdest politician on stage. Matt Wolf's comments in the International Herald Tribune were echoed again and again by reviewers on both sides of the pond: "This Bush is a man possessed of few words but almost fearsome will. . . . Time and again, this play shows a leader quietly taking things in and either accepting them or not, his tendency toward the single word 'yeah' a sign not of weakness but of its opposite." ${ }^{29}$ Furthermore, Hare's President, played in London by Alex Jennings, sharply contrasted with the caricatures of Bush and his cabinet recently seen in Tim Robbins's Embedded (2004) and Justin Butcher's The Madness of George Dubya (2003), giving the Bush of Stuff Happens an even greater appearance of strength.

And yet, in spite of the credence given to Bush, the play still possessed a clear anti-war message. Toby Young, who praised Hare's inclusion of the pro-war viewpoints, simultaneously called the play "the best attack on Bush and Blair I've seen in the theatre so far." ${ }^{30}$ Likewise, John Gross of The Sunday Telegraph insisted that "a hundred aspects of the play-emphasis, omissions, touches of caricatureensure that American policy and British acquiescence stand condemned." ${ }^{31}$ How can the play be both balanced and so directly censure the war? In point of fact, Hare's dialectical technique allows him to do both. By taking Bush and his cabinet seriously, Hare avoids the charge of satire and instead paints them as a dangerous, intelligent group of people with an unstoppable will to follow a premeditated course of action. Secondly, while the pro-war viewpoints may have taken the audience by surprise, they are strategically placed in the first half of the play. The anti-war viewpoints occur in act two and thus provide the final word. Lastly, because of Hare's reputation and his recent editorials, most reviewers expected an extremely leftist, anti-war message. By pulling the play closer to center, Hare earned the praise of even-handedness, even though his indictment of the war remained unmistakable.

Despite Hare's deft manipulation of form and content to impugn the war in Iraq, the immediate political impact of Stuff Happens was minimal. The play inspired 
no speeches against the war from the floor of Parliament, nor did any Members of Parliament hold press conferences praising or condemning the play. Notable reviewers such as Hans Blix, MP Anne Widdecombe, and former MP Robin Cook did not seek out the play of their own accord; they were, in fact, given tickets to the show by London's left-leaning newspaper, The Guardian. The only scandal these high-profile reviews generated was among London newspaper critics, who accused The Guardian of breaking press night etiquette by allowing the VIPs to vet the play before its official opening. ${ }^{32}$ If it were not for the Guardian's explicit invitation to view the performance, it seems unlikely that the cadre of political figures would have commented on the play at all. In the short term, Stuff Happens was a box office success and a significant addition to Britain's canon of state-ofthe-nation plays. Its political efficacy, however, must be measured by the number of individuals who found their beliefs challenged by the viewpoints or were swayed by Hare's argument. This is no insignificant achievement, but the scale remains local, even on the stage of the National.

\section{The Path to 9/11: Failed Mythology}

Exactly two years after the premiere of Stuff Happens, another historical drama made a new attempt to rationalize the war on terror: ABC's made-for-TV miniseries The Path to 9/11. The two-part series was timed to coincide with the fifth anniversary of the 9/11 attacks, which also placed it three-and-half-years into what had become the occupation of Iraq by primarily U.S. forces. At that point, the death toll had risen to 2,875 Coalition soldiers and well over 54,300 Iraqi civilians. While the Iraqi people had held elections and ratified a draft constitution, sectarian violence had driven the country to the brink of civil war. In the United States, the public debate over the continuation of the war had reached a new level of intensity, and President Bush's approval rating had plummeted along with the war's popularity. ${ }^{33}$ Perhaps most importantly, the United States was just months away from a mid-term election in which the Democratic party was poised to seize control of both houses of Congress for the first time in twelve years.

Like Stuff Happens, The Path to 9/11 dramatizes a long series of political maneuvers culminating in a catastrophic event, in this case, the 2001 terrorist attacks. The miniseries opens with the 1993 bombing of the World Trade Center by Ramzi Yousef. From there it follows real-life FBI agent John O’Neill (played by Harvey Keitel) through his investigation of the event and his efforts to protect New York City and the Towers from future terrorist attacks. The plot interweaves O'Neill's story with milestones in the nascent war between the United States and Al Qaeda: the capture of a terrorist's laptop in the Philippines, the prosecution of Ramzi Yousef, the tracking of Osama bin Laden, and the bombing of the U.S. embassy in Nairobi. The overriding message, reinforced through dialogue, action, and visual imagery, is that the September 11 attacks could have been prevented if 
decisive action had been taken at any number of key points. The miniseries climaxes with an extended dramatization of the September 11 attacks. O'Neill-now head of security at the World Trade Center-dies as the South Tower collapses, and the story closes with a report card from the 9/11 Commission: of the Commission's forty-one recommendations to prevent future terrorist attacks, only one area had earned an A; the rest were Ds and Fs.

As in Stuff Happens, The Path to 9/11 depicts high-ranking political figures from recent history (although unlike the play, the television program shows Presidents Bush and Clinton in archival footage only). As Hare did with his play, the creators of the miniseries boasted of the meticulous research that went into its creation. New Jersey Governor Thomas Kean, chair of the 9/11 Commission, served as senior consultant to the film's production team, and director David Cunningham bragged that the movie was accurate down to the ties worn by the actor playing CIA Director George Tenet, which "were taken right from photograph" of the real man. ${ }^{34}$ The educational media firm Scholastic, Inc. - with the sponsorship of ABCissued a series of high school study guides related to the television program, thus framing the broadcast as an educational event. ${ }^{35}$ Most importantly, ABC prominently advertised the miniseries as "Based on the 9/11 Commission Report." Although the Commission Report had its critics, it was and remains the most authoritative document to date that describes the events that led to the September 11 attacks. ${ }^{36}$ The aggregate effect of ABC's efforts created the impression that the miniseries would be, if not a documentary, at least a highly accurate and impartial portrayal of historical events.

At this point The Path to 9/11 diverged significantly from Stuff Happens in that it broke out of the world of entertainment and set off a firestorm in the political arena. In the days leading up to the broadcast, $\mathrm{ABC}$ granted an advance screening to a select group of right-leaning viewers, and the contents of certain scenes were leaked to Bruce Lyndsey, C.E.O. of the Clinton Foundation, and Douglas Band, a legal counselor to Clinton during his presidency. They immediately wrote to Robert Iger, president and C.E.O. of the Walt Disney Company, ABC's parent organization, demanding the revision of "egregious factual errors." Lyndsey and Band pointed out three specific places where the film deviated from the 9/11 Commission Report and other sources and argued that the overall tenor of the changes "suggest that President Clinton was inattentive to the threat of terrorism or insufficiently intent upon eliminating the threat from bin Laden.. ${ }^{37}$ Letters from Sandy Berger and Madeleine Albright soon followed, accusing the film of defaming their reputations by inaccurately portraying their words and actions. Several other ranking Democrats, including Nancy Pelosi and Harry Reid (then minority leaders in the House and Senate), blasted the film for showing obvious bias against the Clinton administration, and by extension, against the entire Democratic party. ${ }^{38}$ Media Matters, a left-leaning media watchdog group, pointed out several factual 
errors in the Scholastic study guides that inaccurately linked the invasion of Iraq to the September 11 attacks, and Scholastic withdrew the materials from their website with apologies. ${ }^{39}$ The controversy sparked a national media frenzy that lasted a fortnight as the film's proponents and detractors battled in the court of public opinion.

In response to the criticism from the members of the Clinton administration, ABC immediately declared that The Path to 9/11 was "not a documentary." 40 The network also revised the offending scenes somewhat, altering dialogue but still portraying the specific inaccuracies and overall tenor cited in the letters from Berger, Albright, Lindsey, and Band. In its own defense, ABC ran a disclaimer at the beginning, middle, and end of both nights of the broadcast:

The following movie is a dramatization that is drawn from a variety of sources including the 9/11 Commission report and other published materials, and from personal interviews. The movie is not a documentary. For dramatic and narrative purposes, the movie contains fictionalized scenes, composite and representative characters and dialogue, as well as time compression. ${ }^{41}$

ABC's disclaimer bears remarkable similarities to Hare's program note for Stuff Happens: a boast of accuracy based on an abundance of sources and a defense of dramatic license. In point of fact, ABC's disclaimer evokes techniques used by history plays for hundreds of years: the combination of multiple historical figures into a single stage presence, the compression of days or years of historic activity into a few moments of stage time, and the invention of dialogue to represent historical attitudes and actions. In this case, the miniseries employed dramatic license rather liberally. For example, one of the most contested scenes involved a moment when C.I.A. operatives are poised to capture Osama bin Laden. They have his camp surrounded. They radio back to Washington to ask for permission to act, but the fictional Sandy Berger (Kevin Dunn) demurs, claiming that he does not have the authority. In the uncut version, Berger was shown hanging up on the C.I.A., an action deleted from the broadcast. In both versions, the moment is lost, and bin Laden goes free. Massoud (Mido Hamada), the leader of the Northern Alliance forces who were to execute the plan, scoffs, "Are there no men left in Washington? Or are they all cowards?" In reality, this situation never took place. It is ostensibly based on a section of the 9/11 Commission Report that describes a proposed plan to capture bin Laden that never materialized. ${ }^{42}$ The miniseries turns that potential plan into a fictionalized - yet highly dramatic - moment of screen time. From the dramatist's point of view, then, the film's creators are operating legitimately within hundreds of years of stage tradition, shaping historical facts into a coherent narrative that will entertain an audience. 
With the weight of theatrical tradition behind the miniseries and ABC's disavowal of any pretense at docudrama, the continued protests from the Democratic party could seem an overreaction. Surely future historians would check their sources before recording that Sandy Berger once hung up on George Tenet and thus missed an opportunity to prevent the events of September 11. However, far more important than posterity for the Democrats were the perceptions of the American electorate. Multiple elements of the film's production and promotion framed it as more than an entertaining historical fiction, the most significant of which was ABC's claim that the program was "Based on The 9/11 Commission Report." In actuality, the film's credits cite three different sources as major influences, none of which appeared in any advertisements. ${ }^{43}$ Visually, the miniseries emulates reality television or live news coverage, with fast cuts, rack focus, and erratic, handheld camera movement. The camera frequently takes position behind obstacles such as fences or window screens, creating the impression that the audience is perpetually "peeking in" on real events. Additionally, the depiction of the September 11 attacks at the end of the miniseries combines footage of the actual events with the staged recreation, thoroughly blurring the visual lines between fact and fiction. In the case of the specific historic events portrayed here, the difference between reality and representation was already obscured, as eyewitnesses to the collapse of the towers described it as "just like a movie," while reviews of 9/11 Commission Report described it as a "thriller" or "a Shakespearean drama." ${ }^{44}$ If Hare's narrative style gave Stuff Happens more of an impression of docudrama than it legitimately deserved, the filmic style of The Path to 9/11 created an even greater sense of documentary.

What concerned the members of the Clinton administration about the framing of the miniseries (its promotion, if not its aesthetic) was the fact that audiences have an increased level of credulity when an account is called history. Literary theorist Roland Barthes calls this the reality effect. The effect, which Barthes discusses in terms of speech-acts, is the process whereby the mere assertion that an event took place makes that event a reality when presented in the context of a historical narrative. "Narrative structure," Barthes argues, "elaborated in the crucible of fictions (through myths and early epics), becomes both sign and proof of reality." 45 Or as contemporary British scholar Richard Palmer puts it in terms of the history play, "a [narrative] that presumes to reenact a historical event makes an appeal for belief that goes beyond the normal request for the suspension of disbelief." ${ }^{\prime 4}$ Canadian columnist Charles Gordon remarked in reaction to The Path to 9/11 controversy that spectators are frequently complicit in these misapprehensions: "We want to believe what we see. When historical figures are portrayed, we want to believe that they did what they did and said what they said. ${ }^{{ }^{47}}$ Carl Becker, in his address as president of the American Historical Society, asserted in 1931 that the average person: 
[weaves history] out of the most diverse threads of information, picked up in the most casual way, from the most unrelated sources ... Daily and hourly ... there is lodged in Mr. Everyman's mind a mass of unrelated and related information and misinformation, of impressions and images, out of which he somehow manages, undeliberately for the most part, to fashion a history. ${ }^{48}$

If Becker is correct, the authority of a source and the accuracy of its information become insignificant when woven into an individual's tapestry of past events: the overall impression is all that matters. Under this rubric, the dramatic moments and half-remembered themes of a made-for-TV-movie become as legitimate a source of history as any official report compiled by an impartial government commission.

Framed by advertisements as authoritative, reinforced by the high school study guides as educational, enhanced by the filmic style as real, The Path to 9/11 became a triple-threat to perceptions of history. Disclaimer or no disclaimer, the members of the Clinton administration worried-and rightly so-that when viewers of the Path to 9/11 thought about the historical events surrounding September 11, they would only remember the fictional narrative of the televised dramatization. And indeed, dozens of newspapers across the country praised the facticity of the miniseries without critically engaging in the debate over its accuracy. ${ }^{49}$ With the program's implicit attack upon the Democratic party within such proximity to the midterm elections, the stakes were too high for the Democrats to ignore. They had to attack the miniseries because they could not take the risk of voters believing the version of history that The Path to 9/11 offered.

Furthermore, whereas Hare's partisan reputation worked to his advantage in Stuff Happens, the circumstances surrounding The Path to 9/11 contributed to its image of bias. The screenwriter, Cyrus Nowrasteh, claimed to be unaffiliated with any political party, but he promoted the film exclusively within conservative organizations, such as Libertas, "a forum for conservative thought on film," and Front Page Magazine, a far-right on-line publication. ${ }^{50}$ Director David Cunningham is associated with an evangelical Christian group founded by his father. ${ }^{51} \mathrm{ABC}$ is owned by Disney, which has recently blocked the distribution of Michael Moore's Fahrenheit 9/11, and Disney also has a vested interest in the state of Florida, at the time governed by the President's brother, Jeb Bush. Furthermore, the entire miniseries ran without commercials, a bold move considering its forty-million dollar price tag. It did break for twenty minutes on the second night to broadcast an address to the nation by President Bush. The address was ostensibly a commemoration of the fifth anniversary of the September 11 attacks, but Bush used the majority of the speech to justify the ongoing war in Iraq, noting that "after 9/11, Saddam's regime posed a risk that the world could not afford to take." ${ }^{\prime 2}$ In effect, the President's 
message promoting the war was the sponsor. All of this took place just two months before a midterm election in which the popularity of the war in Iraq was a key issue. Whether or not there was any actual "conspiracy," the circumstances created the impression of collusion between conservative forces bent on discrediting the Democratic party before a major election. So while the creators of The Path to 9/11 claimed to be neutral, they were perceived as conservative, which only confirmed the accusations of conservative bias.

In the end, the political impact of the miniseries varied in effectiveness. The direct media coverage of The Path to 9/11 ended shortly after it aired, but the questions it raised about Clinton's responsibility for the September 11 attacks echoed into the weeks that followed. In an interview with President Clinton on Fox News Sunday two weeks later, news anchor Chris Wallace asked a question supposedly put to him by viewers: "Why didn't you do more to put bin Laden and Al Qaeda out of business when you were president?"-a topic implicit throughout the miniseries' five hours. The question prompted a vehement and lengthy rejoinder from Clinton as he defended his record, which included a direct reference to The Path to 9/11 as part of the context informing Wallace's query. ${ }^{53}$ Clinton's impassioned response itself become a topic of media coverage, and his reference to The Path to 9/11 briefly brought the miniseries back into the spotlight. As a propaganda piece, The Path to 9/11 ultimately failed, as the Democrats swept the midterm elections in November. Myriad factors contributed to the Democratic success, but the party's overwhelming opposition to the miniseries seemed to have done its job of disarming it. However, the net effect of The Path to 9/11 was something that Hare himself might have been proud of: not only did it dominate national media for days on end, it angered and unnerved audiences up to the highest ranks of power.

\section{Media Matters}

If The Path to 9/11 created a national uproar because it presented a version of history its detractors opposed, why did Stuff Happens not create a similar uproar? Would not the reality effect have applied just as equally to a theatrical narrative that the ruling parties would have found likewise distasteful? In other words, was Stuff Happens less of a threat because it was a play? The contrast throws into relief some of the differences in media between theatre and television, as well as leading to the question of scope versus longevity: which piece will have the greater lasting impact?

The potential risk of attacking a play versus a television movie varies considerably. It is no surprise that the Bush administration ignored the premiere of Stuff Happens-a play appearing in another country on a topic they were trying to avoid. Blair actually came across looking the worse for wear in the play, alternately called a "demented egoist," "a weak sap," or "flummoxed, hapless, [and] bleating" by newspaper critics. ${ }^{54}$ However, for Blair or his representatives to publicly denounce the play would have risked drawing the attention of thousands of people 
who otherwise would never have heard of it, not to mention ensuring sellout crowds. Moreover, Britain has had such a staunch tradition of theatrical freedom since the repeal of the censor in 1968, ${ }^{55}$ that Blair's censuring of a theatrical production would have done more damage to his reputation than suffering the criticism. On the other side of the pond, by calling out The Path to 9/11, the members of the Clinton administration guaranteed that the news media would throw a spotlight on the event. Presumably, they felt that the certain danger of allowing the miniseries to go unchecked outweighed the potential risk of attracting more viewers. Their strategy, therefore, was to take control of the narrative surrounding its release by discrediting the movie before it even aired.

What, then, of the reality effect? Did the theatricality of Stuff Happens, which included double- and triple casting alongside direct addresses to the audience, somehow diminish the play's ability to create a believable portrait of the past? Indeed, some London critics complained of the visual dissonance between the actors and the historical figures they meant to portray, which at times took them out of the performance. However, The Path to 9/11 did not escape this dilemma either; its cast included veterans from television's 24, Everybody Loves Raymond, and The Wonder Years, whose appearances also broke the suspension of disbelief for some reviewers. ${ }^{56}$ In any case, the reality effect is less about seeming real than the perception of truthfulness. While the hyperreality of Path's cinematography enhanced its resemblance to reality television, the sparse staging and verbatim dialogue of Stuff Happens granted it the aura of the stage docudrama. Both narratives spoke in a language meant to resemble the conventional truth narratives accepted by their respective audiences.

One factor remains that cannot be elided or mitigated; besides the aspect of liveness, the essential difference between the theatrical performance and the television broadcast was the sheer scope of the audience. The Path to 9/11 took a disappointing second place among the major television networks on its first night, losing out to NBC's Sunday Night Football. A CNN article dismissed the broadcast with the headline, "Clinton, most Americans, skip ABC's 9/11 Miniseries." ${ }^{57}$ While CNN's assessment was factually correct, part one of The Path to 9/11 still reached an audience of 13 million viewers. Part two took first place among the networks Monday night with 12 million viewers, and it picked up another 2.8 million when rebroadcast on the BBC the following week. ${ }^{58}$ Stuff Happens, on the other hand, played its scheduled fifty-three performances on the 1,100-seat Olivier stage at the National to near sell-out audiences-a success by any theatrical standards. At the end of the two-month run, the play's total viewership stood at just over 50,000 - less than one-half of one percent of the number of people who saw The Path to 9/11 in just two nights. These numbers alone made The Path to $9 / 11$ a force to be reckoned with, while Stuff Happens could be safely ignored. 
Scope however, is not the only measure of efficacy; another is longevity. In the same month as the 2006 midterm elections, The Path to 9/11 received seven Emmy nominations (all for technical merits) and won two "Freedom of Expression" awards from the right-wing Liberty Film Festival. Two months after that, it created a smattering of commentary on Fox News when $\mathrm{ABC}$ released the scenes it cut from the broadcast. Since then, the miniseries has faded almost entirely from view, and the lack of a DVD release has made it inaccessible to anyone who did not watch or record the original broadcast. With but a single performance, the mediatized narrative has proven more ephemeral than its theatrical counterpart.

In the case of Stuff Happens, the play lingered nearly a year after its run at the National Theatre before it was produced in the United States-not in New York, but at the Mark Taper Forum in Los Angeles. It was another year before it played in New York - not on Broadway, but in the Public Theater. The delays suggest anxiety among producers over how American audiences would respond to a play so critical of the sitting administration - or perhaps anxiety about a play with so large a cast and so little action. However, after the New York production played to sold out houses, garnered outstanding reviews, and won three Lucille Lortel awards, the play has been in near continuous production across the United States, Canada, and even Australia. ${ }^{59}$ Reviewers' opinions have varied about its continued relevance as political theatre and its effectiveness as drama; however, as the play's originating events recede, its potential as drama-rather than docudrama-has come to fruition. For example, in 2007, the Pittsburgh Irish \& Classical Theatre produced Stuff Happens in repertory with Julius Caesar as part of a series titled "The Price of Empire," with the same actors doubling as Powell-Brutus and Rice-Portia. In this context, Stuff Happens not only gains cultural clout from the association with Shakespeare, but it represents a shift from perceiving the play as a political treatise of "crude propaganda" to seeing it as a disquisition on the themes of power and responsibility. Hare-the-artist has ultimately trumped Hare-the-researcher.

Over six years, the number of people who have seen Stuff Happens in at least ten major productions remains dwarfed by the number of people who watched The Path to 9/11 in a single broadcast; however, the more often Stuff Happens plays, in more venues, with more diverse production choices, the greater its potential to produce the reality effect. The comparison between Stuff Happens and The Path to 9/11 resembles a formula for calculating physical force: The Path to 9/11 impacted a massive amount of people over a very short period of time. Stuff Happens has impacted a far smaller number of people over a much greater period of time. In fact, if the play's production history over the last few years is any indication, we have not even reached the half-life of its potential. Moreover, unlike the television program, which is lost to the public barring an unlikely rebroadcast or DVD release, the play persists as a readily available text that can be bought and read. It was also anthologized in the fifth edition of the Wadsworth Anthology of Drama, virtually 
guaranteeing its immortality in theatre history.

As Carl Becker suggests, what actually happened in the past matters far less than what people believe to have happened. In the long term, those who did not experience the events of 2001 to 2003 directly will have to rely on the historical accounts of those events - including accessible dramatic adaptations. Given the innumerable sources and types of media that record events in the modern world, it seems unlikely that either Stuff Happens or The Path to 9/11 will have a decisive voice in future debates over the war on terror. However, historical myths do not depend on official conclusions; they emerge from the total accumulation of data, accurate or not. In the future, a history play on a war from a previous century, whether made newly relevant by local events or staged merely as a period piece, would irrevocably become part of the mythos of history.

There is no denying the immediate impact of The Path to 9/11. It caused a political ruckus the likes of which Hare and Brenton of Portable Theatre would have envied. However, Stuff Happens is exactly the kind of enduring work that builds a myth over time. Benedict Nightingale reported that he left Stuff Happens "wondering ... about the accuracy and therefore the authority of a play whose author admits he's 'used my imagination' to fill in the bits not on public record. And yet again and again I felt that yes, this is how it was. ${ }^{{ }^{60}}$ And to be sure, The Path to 9/11 had proponents who felt just as strongly that it was true. Both pieces attest to the power of storytelling to change the very truth of past events, no matter the media.

\section{Notes}

1. For a sample advertisement, see: "The Path to 9/11." Advertisement. Life: America's Weekend Magazine 8 Sept. 2006: back page. The screenwriter, Cyrus Nowrasteh, is quoted in: Govindini Murty, “ABC's 'The Path to 9/11' Is Outstanding," rev. of The Path to 9/11, by Cyrus Nowrasteh, dir. David L. Cunningham. ABC. Human Events Online, 22 Aug. 2006, 13 Sept. $2006<$ http://www.humanevents. com/article.php?id=16621>. The director, David Cunningham, is quoted in: Frazier Moore, "What can we learn from ABC's Folly? The unintended lessons of The Path to 9/11," Associated Press Financial Wire, 12 Sept. 2006.

2. Bruce R. Lindsey \& Douglas J. Band, "To Robert Iger," 1 Sept. 2006, "Full Text Of Letter From Bill Clinton Lawyer To ABC Obtained," by Greg Sargent TPMCafe.com, 13 Sept. $2006<\mathrm{http}: / /$ www.tpmcafe.com/blog/electioncentral/2006/sep/07/full_text_of_letter_from_bill_clinton_lawyer_ to abc obtained $>$.

3. The letters from Berger and Albright, both dated September 5, 2006, were posted on CNN. com. See: "Clinton blasts 9/11 film, amid report of changes," CNN.com. Cable News Network 8 Sept. 2006, <http://www.cnn.com/2006/SHOWBIZ/TV/ 09/08/abc.movie/index.html >. The letters of protest are reported in Moore.

4. Kate Bassett, "Men at war: Stuff Happens is absorbing, but how much spin doctoring has gone into it," rev. of Stuff Happens, by David Hare, National Theatre, London, dir. Nicholas Hytner, Independent on Sunday 12 Sept. 2004: 16.

5 . Hans Blix, "Reviewing myself," rev. of Stuff Happens, by David Hare, National Theatre, London, dir. Nicholas Hytner, The Guardian 14 Sept. 2004. 
6. Ann Widdecombe, MP, et al., "For or against? Whatever the critics make of it, David Hare's Stuff Happens is undeniably one of the cultural events of the year," revs. of Stuff Happens, by David Hare. National Theatre, London, dir. Nicholas Hytner, The Guardian 3 September 2004: Features 2+. Blair is quoted in Jesse McKinley, "David Hare Enters the Theatre of War," New York Times 26 March 2006, late ed.: B1.

7. Hare's program note insisted that "nothing in the narrative is knowingly untrue," Stuff Happens, rev. ed. (London: Faber \& Faber, 2006) vi, while film critic Govindini Murty claimed that it "simply presents the facts in an honest and straightforward manner." "ABC's 'The Path to 9/11' Is Outstanding."

8. Iraq Coalition Casualty List, eds. Pat Kneisler and Michael White. Updated daily, 1 Oct. 2009 $<$ icasualties.org>. Iraq Body Count, eds. Hamit Dardagan and John Sloboda. Updated daily, 1 Oct. 2009, <iraqibodycount.org>.

9. Quoted in: Misha Berson, "A Seat in the War Room," rev. of Stuff Happens, by David Hare, ACT Theatre, Seattle, Dir. Victor Pappas, Seattle Times 28 June 2007: D1.

10. Hare 120 .

11. Racing Demon (1990), Murmuring Judges (1991), and The Absence of War (1993). For a comprehensive discussion, see Les Wade, "Hare's trilogy at the National: Private moralities and the common good," The Cambridge Companion to David Hare, ed. Richard Boon (Cambridge: Cambridge U P, 2007).

12. David Hare, "Comment \& Analysis: Don't look for a reason: All the explanations for this war are bogus," The Guardian 12 April 2003: 21. Hare, Betrayed: David Hare used to have an instinctive sympathy for politicians," The Guardian 23 June 2003: Features 2. Notably, many of the themes in Stuff Happens can be found in these two essays.

13. Max Hastings, David Aaronovitch, et al., "For or against? Whatever the critics make of it, David Hare's Stuff Happens is undeniably one of the cultural events of the year," revs. of Stuff Happens, by David Hare, National Theatre, London, dir. Nicholas Hytner, The Guardian 3 September 2004: Features 2+. See also Roger Foss, What's On, rev. of Stuff Happens, by David Hare, National Theatre, London, dir. Nicholas Hytner, 5 Sept. 2004.

14. Matt Wolf, “A wily, prickly portrait of Bush,” rev. of Stuff Happens, by David Hare, National Theatre, London, dir. Nicholas Hytner, International Herald Tribune 15 Sept. 2004: 11. Sheridan Morley, "Play that does not make a drama of a bloody war," rev. of Stuff Happens, by David Hare, National Theatre, London, dir. Nicholas Hytner, The Express 15 Sept. 2004: 30.

15. Charles Spencer, "Hare victory as theatre becomes war forum," rev. of Stuff Happens, by David Hare, National Theatre, London, dir. Nicholas Hytner, Daily Telegraph 11 Sept. 2004: 6.

16. Hare, Stuff Happens vii.

17. Christopher Rawson, "Stranger than Fiction: Playwright David Hare Fills in the Details of the Iraq War Buildup in Stuff Happens, ” Pittsburgh Post-Gazette 10 May 2007, sooner ed.: Arts 1+.

18. Donna Soto-Morettini, "Trouble in the House: David Hare's Stuff Happens," Contemporary Theatre Review 15.3 (2005): 209-319, 312.

19. Stephen Bottoms, "Putting the Document into Documentary," TDR: The Drama Review 50.3 (Fall 2006): 56-68, 60.

20. Rawson.

21. Quoted in Misha Berson, “A seat in the war room," Seattle Times 28 June 2007, fourth ed.: D1.

22. Only five months previously, Hare's docudrama on the British railway system The Permanent Way played at the National Theatre to near universal acclaim, and Hare showed some anxiety about gaining a reputation as a theatrical journalist. In an address given just a month after Stuff Happens premiered, Hare insisted upon the artistry behind all theatre, even that based upon factual or political subjects: "The creation of a great political play will demand exactly the same measure of genius, torture, and art as the creation of any other. And maybe more. . . Stuff Happens . . absorbed and stretched me as completely as anything I wrote in my youth." Obedience, Struggle, and Revolt: Lectures on Theatre (London: Faber and Faber, 2005) 27.

23. Ben Brantley, "Current-Event Cartoons As the Stuff of Theatre," New York Times 13 Sept. 2004, late ed.: E1.

24. For Hare's comments, see Rawson and Catherine Foste, "Tough campaign for a play about Iraq war," Boston Globe 15 Oct. 2006, first ed.: N1. For the encounter between Bin Laden and British 
forces, see Stuff Happens 28-30.

25. Quoted in Foster.

26. Bassett 16.

27. Hare, Stuff Happens 14-15.

28. Toby Young, rev. of Stuff Happens, by David Hare, National Theatre, London, dir. Nicholas Hytner, The Spectator 18 Sept. 2004.

29. Wolf 11. Iris Smith Fischer points out that the same technique was used throughout NBC's television series The West Wing as an indication of "agreement and solidarity" between the fictional President Bartlett and his staff (personal correspondence).

30. Young.

31. John Gross, rev. of Stuff Happens, by David Hare, National Theatre, London, dir. Nicholas Hytner, Sunday Telegraph 19 Sept. 2004.

32. Jane Edwardes, "Jumping the Run," Time Out 22 Sept. 2004: 145.

33. Steven Ruggles, "Historical Bush Approval Ratings," Department of History, 20 June 2008, University of Minnesota, 1 Oct. $2009<$ http://www.hist.umn.edu/ ruggles/Approval.htm>.

34. Quoted in Moore.

35. "ABC-Sponsored teaching materials falsely suggest Iraq had WMD, link War in Iraq to 9/11," Media Matters For America 6 Sept. 2006, 11 Oct. $2006<$ http://mediamatters.org/items/200609060005>.

36. All sides of the Path to 9/11 controversy consistently referenced The 9/11 Commission Report as their source of historical fact, and even such popular sources as Saturday Night Live (NBC, 16 Sept. 06) have referred to the Report as "the voice of history." However, the Report is not without criticism; see, for example, Benjamin DeMott's article, "Whitewash as Public Service: How The 9/11 Commission Report Defrauds the Nation," Harpers.org. Harper's Magazine, 12 Nov. 2004, 15 Nov $2006<$ http:// www.harpers.org/WhitewashAsPublicService.html>.

37. Lyndsey and Band.

38. CNN, "Clinton."

39. Scholastic removed the materials on September 6 and posted a letter explaining that they were "not in keeping with our high standards": "Dear Teacher of Social Studies, grades 9-12," Scholastic. com, 6 Sept. 2006, 21 May $2010<$ http://www.scholastic.com/ medialiteracy>.

40. "Clinton blasts $9 / 11$ film, amid report of changes," CNN.com. Cable News Network, 8 Sept. 2006, 21 May $2010<$ http://www.cnn.com/2006/SHOWBIZ/TV/ 09/08/abc.movie/index.html>.

41. The Path to 9/11, by Cyrus Nowrasteh, dir. David L. Cunningham perf. Harvey Keitel, ABC, 10 \& 11 Sept. 2006

42. "National Commission on Terrorist Attacks Upon the United States," The 9/11 Commission Report authorized edition (New York: W.W. Norton, 2004).

43. John Miller and Michael Stone, with Chris Mitchell, The Cell: Inside the 9/11 Plot, and Why the FBI and CIA Failed to Stop It (New York: Hyperion, 2002). Peter Lance, 1000 Years for Revenge: International Terrorism and the FBI (New York: Harper, 2004). Samuel Katz, Relentless Pursuit: The DSS and the Manhunt for the Al-Qaeda Terrorists (New York: Forge, 2002).

44. Bill Schaffer, "Just Like a Movie: September 11 and the Terror of Moving Images," Senses of Cinema, Nov. 2001, 1 Oct. $2009<$ http://archive.sensesofcinema.com/contents/01/17/symposium/ schaffer.html>. Thomas Crampton, "If 9/11 Report Wins Award, Will 90 Authors Rise," New York Times 24 Oct. 2004: 21. "The 9/11 Commission Report," rev. of The 9/11 Commission Report, by the 9/11 Commission, Publisher's Weekly 16 Aug. 2004: 56.

45. Roland Barthes, "The Discourse of History," 1967. In The Rustle of Language, trans. Richard Howard. (New York: Hill and Wang, 1986) 140.

46. Richard Palmer, The Contemporary British History Play (London: Greenwood, 1998) 7. I have used this formulation between Barthes and Palmer previously in Jay M. Gipson-King, "Wertenbaker and the Metahistorical: Fracturing History in The Grace of Mary Traverse, The Love of the Nightingale, and After Darwin," International Dramaturgy: Translations and Transformations in the Theatre of Timberlake Wertenbaker, eds. Sara Freeman and Maya Roth (New York: Peter Lang, 2008) 223-34, 230.

47. Charles Gordon, "Improving on History: A Factual Emergency," Ottawa Citizen 18 June 2006: A12. Emphasis added.

48. Carl Becker, "Everyman His Own Historian," address to the American Historical Association, 
Minneapolis, 29 Dec. 1931, American Historical Association, 12 Dec. $2006<\mathrm{http} / / / w w w . h i s t o r i a n s$. org/info/AHA_History/clbecker.htm>.

49. Josh Kalven, "Numerous reviews of ABC miniseries failed to note controversy surrounding its factual accuracy," Media Matters for America, 11 Sept. 2006, 11 Oct. $2006<$ http://mediamatters. org/items/200609120002>.

50. Jamie Glazov, "The Path to 9/11," FrontPageMagazine.com 16 Aug. 2006, 20 July 2007 $<$ http://www.frontpagemag.com/Articles/ReadArticle.asp?ID=23865>. Govindini Murty, "Interview: Writer-Producer Cyrus Nowrasteh on his 'Into the West' and '9/11' Miniseries," Libertas 9 June 2005, 20 July $2007<$ http://www.libertyfilmfestival.com/libertas/index.php?p=462>. Nowrasteh describes his own political leanings in: "Detours off the Path to 9/11," Written By December 2006, Writers Guild of America-West, 16 July $2007<$ http://www.wga.org/writtenby/writtenbysub. aspx?id=2269>.

51. David Leigh, "BBC did not know of $9 / 11$ film's link to religious right," Guardian 13 Sept. 2006, final ed.: 5 .

52. George W. Bush, "President's Address to the Nation," 11 Sept. 2006, The White House, 22 Jan 2006 <http://www.whitehouse.gov/news/releases/2006/09/20060911-3.html>.

53. Josh Kalven and Robert Dietz, "Wallace falsehood: said in Clinton interview that he asked Bush admin officials 'plenty of questions' about failure to catch bin Laden,." Media Matters for America, 24 Sept. $2006<\mathrm{http}: / /$ mediamatters.org/items/200609240002>.

54. Michael Billingtong, "Not agitprop, but the history of a war compellingly told," rev. of Stuff Happens, by David Hare, National Theatre, London, dir. Nicholas Hytner, The Guardian 11 Sept. 2004: Home 7. Benedict Nightingale, "Good stuff, as it happens," rev. of Stuff Happens, by David Hare, National Theatre, London, dir. Nicholas Hytner, The Times 11 Sept. 2004: Features 23. Quentin Letts, "Theatre of War," rev. of Stuff Happens, by David Hare, National Theatre, London, dir. Nicholas Hytner, Daily Mail 13 Sept. 2004: 13.

55. Official freedom from the censor, though, stopped neither the public prosecution of Howard Brenton's The Romans in Britain in 1980 nor the lambasting of Sarah Kane's Blasted by London critics in 1995-both ostensibly attacked for graphic depictions of sexual violence, rather than politics.

56. See, for example, Robert Hanks, "Stuff Happens," rev. of Stuff Happens, by David Hare, National Theatre, London, dir. Nicholas Hytner, Independent 14 Sept. 2004: Features 17. Ken Tucker, "The Path to 9/11," Rev. of The Path to 9/11, by Cyrus Nowrasteh, dir. David L. Cunningham, ABC, EW.com, 11 Sept. 2006, Entertainment Weekly, 7 Oct. $2009<$ http://www.ew.com/ew/article/0, 1516013,00.html>.

57 “Clinton, most Americans, skip ABC's 9/11 Miniseries,” CNN.com, Cable News Network, 11 Sept. $2006<$ http://www.cnn.com/SHOWBIZ/>.

58. For U.S. viewership, see: "Broadcast TV Ratings for Sunday, September 10, 2006," Your Entertainment Now, 11 Sept. 2006, 22 Jan $2006<$ http://entertainmentnow.wordpress.com/2006/09/11/ broadcast-tv-ratings-for-sunday-september-10-2006/>. "Broadcast TV Ratings for Monday, September 11, 2006," Your Entertainment Now, 11 Sept. 2006, 22 Jan $2006<$ http://entertainmentnow.wordpress. com/2006/09/11/broadcast-tv-ratings-for-monday-september-11-2006/>. For U.K. viewership, see Leigh.

59. The first professional U.S. production was at the Mark Taper Forum in Los Angeles in June 2005, followed by productions at the Public Theater in New York in April 2006, Boston's Zeitgeist Stage Company in October 2006, the Pittsburgh Irish and Classical Theatre in April 2007, Seattle's ACT in July 2007, Studio 180 in Toronto in March 2008, and Georgetown University and the Olney Theatre Center in Washington D.C. in April and June 2008. It was also produced in Sydney in July 2005.

60. Nightingale 23. 